\title{
Internet Media as Component of Information and Communication Environment in Electoral Process: Features and Tools
}

\author{
Vitaly V. Tomin ${ }^{{ }^{*}}$ \\ (iD) 0000-0002-7679-843X SC 57189319730 A-5148-2016
}

Natalia E. Erofeeva ${ }^{2}$

(D) 0000-0002-2135-8859 SC 57188838322 C-3867-2015

Tatiana V. Borzova ${ }^{3}$

(D) 0000-0002-2307-9001 SC 57205363884

Tatyana B. Lisitzina 4

(iD) 0000-0003-3951-7907 SC 56260801300 A AAC-9932-2020

Vladimir E. Rubanik ${ }^{5}$

(iD) 0000-0002-8837-241X SC 57212510746 D।-1723-2018

Hibi K. Aliyev ${ }^{6}$

(iD) 0000-0001-9321-5550 SC 57211539492

Pari G. Shuaipova ${ }^{7}$

(iD) 0000-0002-4235-0311 SC 57211474626 AAD-2020-2020

${ }^{1}$ Department of Foreign Languages, Orenburg State University, Orenburg, RUSSIA

${ }^{2}$ Orsk Humanitarian-Technological Institute (Branch), Orenburg State University, Orsk, RUSSIA

${ }^{3}$ Department of Psychology, Pacific National University, Khabarovsk, RUSSIA

${ }^{4}$ Department of Social and Cultural Activities and Tourism, Gzhel State University, Ramensky District, RUSSIA

${ }^{5}$ Department of Legal Regulation of Economic Activity, Financial University under the Government of the Russian Federation, Moscow, RUSSIA

${ }^{6}$ Department of Criminal Procedure Law, North Caucasian Institute (Branch), All-Russian State University of Justice (RPA of the Ministry of Justice or Russia), Makhachkala, RUSSIA

${ }^{7}$ Department of Civil Law, Rostov Institute (Branch), All-Russian State University of Justice (RPA of the Ministry of Justice or Russia), Rostov on Don, RUSSIA

* Corresponding author: vnimot@yandex.ru

Citation: Tomin, V. V., Erofeeva, N. E., Borzova, T. V., Lisitzina, T. B., Rubanik, V. E., Aliyev, H.K., \& Shuaipova, P. G. (2020). Internet Media as Component of Information and Communication Environment in Electoral Process: Features and Tools. Online Journal of Communication and Media Technologies, 10(3), e202011. https://doi.org/10.29333/ojcmt/7932

\section{ARTICLE INFO}

Received: 22 Oct 2019

Accepted: 21 Feb 2020

\section{ABSTRACT}

The relevance of this article lies in the need to study Internet media in the information and communication environment, since new media technologies have entered the arena of election communication, the role of which is increasing both in the campaign process and in the election campaign as a whole. The purpose of the study is to determine the features of new media use in election campaigns in Russia. Research methods: as a research method, we used the method of individual in-depth interview, which allows us to identify and characterize the main methods of using new media technologies in election communication. Research results: the article shows the main ways and methods of using new media in election campaigns. The reasons and prerequisites for the use of new media technologies for the implementation of the electoral process are highlighted. The factors that determine the low level of new media use in the election campaign are determined. The effectiveness of new media functions in the electoral process is shown. The main prospects of development in the use of new media in election campaigns are 
considered. The novelty and originality of the study lies in the fact that the features of Internet media use in the electoral process are studied. For the first time, we the properties that allow new media technologies to use them in a completely different aspect than traditional media are identified: interactivity, multimedia content, efficiency in publishing, low cost and high speed of distribution of information content, as well as its availability and the ability to provide targeted information. It is determined that due to the above-mentioned properties of new media in political communication the following goals are achieved: presentation of political projects, the impact of the highlighted agenda on certain segments of the population, disseminating information about the activities of a candidate or party, collecting funds for the campaign, as well as the interaction with means of mass communication. For the first time, the functions of Internet media in the electoral process are highlighted, which are relevant: information-based, public opinion formation, mobilization, advertising, collection of monetary donations, and control over the conduct of election campaigns. It is shown that for Pro-government campaigns, the main functions of Internet media in the electoral process are information-based, formation of public opinion and image of the candidate, legitimization of the election process in the mass media, and the function of an additional source of information. For non-system opposition, the main functions of Internet media in the electoral process are information-based, communication, mobilization (which are especially manifested in the organization of volunteers' work), the formation of the candidate's image, and the collection of monetary donations. It is determined that the use of new media technologies by Pro-government campaigns differs significantly from opposition campaigns. It is shown that Pro-government candidates actively use traditional methods of interaction with voters: outdoor advertising, print media, local and Federal TV channels, not letting opposition candidates into it. It is determined that the technologies used by the headquarters of candidates from the government are less diverse and do not change over time. Interaction tools depend on the candidate and local electoral specifics. It is revealed that communication on media platforms between opposition supporters is more emotional, sincere, and fanatical. These people are distinguished by having a strong internal position and committed attitude to the policy of a representative of the non-system opposition. It is determined that the media services of the headquarters of Pro-government candidates mainly provide information presence of the candidate, explanatory rhetoric and legitimization of the election process on the media platforms. For the first time, it is revealed that even on new media platforms, Pro-government campaigns for the most part continue to use the vertical model of communication, placing the main emphasis on administrative resources. It is shown that the role of new media will grow more and more.

Practical significance: the data Obtained in this work can be used in social psychology, pedagogy, age psychology, sociology, as well as for further theoretical development of this issue.

Keywords: internet, internet media, media technologies, election process

\section{INTRODUCTION}

The activities carried out by the election headquarters to attract votes of supporters are aimed at creating political communication between voters and the candidate, in the process of which an impact is made on the political object, that is, on the voter (Alisov et al., 2018; Dmitriev, 2002; Pilgun, 2012; Tavokin, 1996; Vershinin, 2003).

There are many approaches to defining political communication. All pre-election work is aimed at directing the largest part of the electoral body in the direction of a certain candidate (Darren, 2010; Kiselev, 2007; Ponomarev, 2007; Solovjov, 2004; Zalessky, 2000).

Within the framework of an election campaign, a management entity (the headquarters of a candidate or party) initiates communication with the target audience (the electorate) in order to influence public opinion through messages that are transmitted through the media (Gelman, 1997; Lapaeva, 2002; Lukina, 2010; Miroshnichenko, 2003; Solenikova, 2007).

Thanks to the development of the Internet, new forms of dialogue between the government and society have emerged. In our work, we will consider the features of building political communication during the election campaign using new media. New media is a concept that belongs to a series of conceptual innovations in the interdisciplinary analysis of sociocultural changes at the beginning of the new Millennium, related to the emergence of computer networks, the Internet, digital storage and data transmission systems, and the convergence of various means of communication (Anokhin \& Pavlyutenkova, 2001; Baranov et al., 
2019; Galkin, 2000; Ivanov, 2002). Thus, the emergence of new media is due to the development of computer technologies, thanks to which changes take place in social communication (Boyarova, 2011; Kislitsina, 2009; Losenkov, 2006).

If we consider new media as a means of social communication on the Internet, including political communication, we can distinguish a number of specific properties: interactivity, multimedia nature, efficiency in publishing information, cheapness, and high speed of information dissemination, availability of published information, agitation and propaganda activities. Some researchers note that with the help of the Internet, which is popular among young people, it will be so possible to interest them in politics that they will simply be eager to vote (Cherdymova et al., 2019; Cheredov, 2009; Grachev, 2003; Putilina et al., 2019; Tsabolova et al., 2019). It has been suggested that the specifics of political information on the Internet (its large volume, completeness, and depth) will attract potential voters who are confused and deterred from participating in elections by the shallowness and bias of political materials in traditional media (Brodovskaya, 2013; Kaminchenko, 2013; Martjanov, 2013; Smorgunov, 2014). Thus, the development of Internet technologies and the convergence of mass media provide more and more ways to interact with users. Representatives of the political sphere were among the first to use new media technologies in their propaganda activities. Mostly, we can say that all political activity is aimed at gaining credibility and trust among voters in order to win elections and ensure the politician's power. Therefore, the borders of the territory where the political struggle is being waged (this is especially acute before the elections) have been expanded in the last decade, covering not only the real, but also the virtual space. Recently, new media platforms are being used to raise money for the campaign. Politicians are actively beginning to learn an important feature of new media technologies - interactivity. Internet platforms have become a place of active expression of the opposition sentiment of the population, as well as the birthplace of opposition leaders (Alexandrov, 2011; Mikhaleva, 2009; Shashkova, 2011).

New media technologies now allowed not only to influence the users' perception, but also made it possible to organize social processes. Politicians try to attract supporters of their activities in order to get money donations from them to implement their goals. (Achkasov \& Chugunov, 1998; Chugunov, 2000; Ovchinnikov, 2002; Peskov, 2002; Yudaev, 2001). Thus, citizens who are particularly loyal supporters can provide financial support to their candidate. The websites of politicians and political parties participating in elections have changed. They have become more interesting, dynamic, and visually pleasing to view. In addition, candidates constantly answered users' questions on their websites. Politicians began to understand that constant communication with voters on the Internet is not only a way to find out the issues of concern, but also a way of campaigning.

\section{MATERIALS AND METHODS}

The method of individual in-depth interviews was used to interview specialists with different attitudes to the interaction of new media and the election campaign, specialists with experience in various election campaigns and specialists working in election headquarters.

Almost all participants noted that now the nature of election campaigns is divided into two types: campaigns of candidates from the current government (this also includes candidates from parliamentary parties) and campaigns of candidates from non-system opposition.

The objectives of the study are as follows:

to identify the main ways and methods of using new media in election campaigns; to identify the reasons and prerequisites for the use of new media technologies for the implementation of the electoral process; to study the factors that cause a low degree of new media use in the election campaign; to study the effectiveness of new media functions in the electoral process (information, communication, public opinion formation, mobilization, advertising, aimed at forming the image of the candidate, collecting donations, monitoring the conduct of election campaigns); to identify the main development prospects in the use of new media in election campaigns.

The following questions were asked in the interview: 
Do you think that Internet technologies can currently serve as the main tool for creating a dialogue between a candidate and voters? Why? If they cannot, what factors influence this?

Do you think the nature of modern election campaigns has changed? How?

Why do you think these methods were used? What goals were you trying to achieve? How successful was it?

Can you tell what ways of using new media in election campaigns you know? Which of them are the most effective?

What new media technologies were used in election campaigns with your participation?

What are the prospects for developing the use of new media technologies in the election process? What innovations do you think we will see in the next regional or Federal campaign?

\section{RESULTS}

All participants in the study have more than ten years of experience in elections, so the informants were asked whether they thought the nature of election campaigns had changed in recent years. Almost all respondents (89\%) clearly noted the presence of changes. However, each of them highlighted the features. Some (24\%) noted a change in communication between voters and government representatives, namely the emergence of new media channels for information interaction. Since now many Internet users of electoral age are in social networks (99\%) (Twitter, Facebook, Odnoklassniki, Vkontakte, Livejournal), there is a need to work on new media platforms. This work includes creating informational events, tracking the nature of comments, and distributing information about the candidate and his / her program on the Internet. Some informants (13\%), who work mainly for Pro-government campaigns, note that now social media is used not so much for information interaction as for legitimization of the election process. Voters form an opinion about the integrity of the ongoing elections. At the same time, it is noted that in this case, the regional factor plays a role (76\%): in large cities, more attention is paid to this process than in small ones. Now, according to informants, almost all Internet communication platforms are used during the election campaign (Facebook, Vkontakte, Odnoklassniki, Twitter, and Blogosphere). Websites of candidates and groups of supporters are created. The degree and intensity of certain network resources' use depends on several factors: the level of elections, the specifics of the region, the activity of the local population on the Internet, the electoral portrait of a party supporter or candidate, an order from the top and from the campaign Manager who decides on the directions of campaign work. Now even small municipal campaigns have to pay attention to the activity of the local population on the Internet. "At the moment, every municipality has a forum, an Internet platform. They are active everywhere, there are people sitting everywhere who sit and describe any information. People are interested in city life. Any site needs to be moderated in some way, so we will attract some bloggers to ensure that everything is smooth there, too." (Female, 41 years old) according to our oppositionists (89\%), the candidate is the next stage after the politician. You cannot win elections fairly if you have not worked for your political image before. It takes time. "Before going to the polls, a loyal audience must be formed and this is real politics, a Politician must grow; a politician must go with an electorally significant resource." (Male, 43 years old) As for the campaign of supporters of the current government, it is often the opposite. Having an administrative resource is a big advantage. This is noted in $99 \%$ of the responses. In these campaigns, we rather see interaction with voters not horizontal like the opposition, but from top to bottom. Thus, it is not surprising that our non-systemic opposition does not just disagree with the interests of the current government, but also actively tries to resist it.

Domestic campaigns can be divided into Pro-government and opposition campaigns (where representatives of non-system opposition participate). Campaigns of government candidates are characterized by intensive use of administrative resources (98\%), thus closing traditional channels of interaction with voters (television, press, radio). This leads to the fact that it is in campaigns of non-systemic opposition that new media technologies are used with much greater intensity and creativity. The effect of such use is obvious, but now, since new media is not yet the main channel of interaction with the electorate, and administrative methods of influence are strong, this is not enough to win for the opposition candidate. 
Summing up the above-mentioned, we note that now in Russian election practice, there is a clear confrontation between two forces: the government and the non-system opposition, which is based on a different approach to building communication between the candidate and voters. For this reason, the same new media platforms are used by Pro-government and opposition campaigns in different ways and with different efficiency. When evaluating the communication function of new media, informants divided the directions of its implementation. The study participants evaluate horizontal communication of the active electorate in the network as effective one (88\%), while discussing the communication of users among themselves, the participants tell how simple communication mobilizes supporters to meetings, taking part in events (98\%). Communication between users and the candidate is not always successful and effective. When implementing the function of forming public opinion, you need to take into account several features. With the help of new media, voters can create a positive image of the candidate, but this cannot be done here and now. It takes time, long and intensive work towards the correct presentation of content. This is the only way to grow a politician to the level of a candidate, that is, to make him/her worthy of lobbying for the interests of voters in power. Some informants (32\%) believe that well-known and respected people play a huge role in shaping public opinion, which should be taken into account when building communication in this direction. Sometimes this is not used fairly.

Our participants to create the candidate's image also use new media. Some of them use the Internet for this purpose, for the subsequent translation of this information into traditional mass media (79\%). As for fundraising via the Internet, this function is considered effective only by representatives of the opposition (63\%). This is not used in the campaigns of government candidates. In addition, informants working on Progovernment campaigns do not believe in the effectiveness of such a process in our country. Analyzing the experience of informants in implementing the above-mentioned functions in election campaigns, we can conclude that due to limited opportunities in using all channels of interaction with voters, representatives of non-system opposition have to more intensively and more creatively explore the space of new media to achieve their goals. The use of new media by Pro-government campaigns is more similar to the use of traditional media. Often having a large administrative resource, they usually do not set goals to actively and effectively agitate Internet users and force them to activity. This is more like controlling information content on new media platforms, creating it to ensure the effect of the candidate's presence, and counterpropaganda.

\section{DISCUSSIONS}

New media have made huge changes in the elective communication processes due to their properties that distinguish them from traditional mass media. Among these specific features, we identified interactivity, multimedia, efficiency in publishing, cheapness and high speed of distribution of information content, as well as its availability and the ability to provide targeted information. Analyzing the degree of new media use in election campaigns, we can conclude that at this stage, the candidates do not use all the power of new media technologies. But some election staffers used this feature. When distributing information through social networks and other Internet resources, it was necessary to take into account the creativity of the information product being distributed. The more unusual and creative the authors of this material are to create it, the faster this product is distributed to the Internet and better remembered.

New media is beginning to be used not only in Federal elections. Regional election campaigns are also beginning to incorporate new media technologies into their process. Regional elections are characterized by a smaller size of the territory where local elections are held, often these territories are far from Federal centers, and, consequently, have a lower degree of Internet penetration and certain features of media consumption.

Because of the heterogeneity of society, namely the division into leaders of public opinion and ordinary citizens, there is a need to work with these authoritative and respected people, so that they, in turn, broadcast the necessary information to the masses, who trust their leaders and will listen to their position. In modern society, public opinion leaders have also appeared in the Internet space - bloggers, journalists who have thousands and hundreds of thousands of subscribers, so they can form the desired position of the voter with information broadcast to the masses. This is confirmed by the experience of our participants. 
The implementation of the mobilization function also has its own specifics, despite the fact that, according to informants, the Network plays a huge role in this. The participants note that it is almost impossible to measure statistically how many people came to a rally, for example, thanks to the Internet. The effectiveness of mobilization is affected by the need to take into account the characteristics of the audience. If you have found your audience Online, then it is possible. A single opinion was expressed that now, in the current political conditions, it is becoming more difficult to mobilize supporters for any purpose. Since the government itself creates obstacles to the implementation of the opposition's initiative, there is also a drop in activity due to disappointment in the current socio-political situation.

\section{CONCLUSION}

Summing up the overall results of the study, the following generalizations and conclusions can be made. Despite the fact that new media has been actively used in the global election practice for several years, this phenomenon has not received mass distribution in our country. Almost all election campaigns in Russia now use new media technologies with varying intensity to build communication with voters. However, this process certainly has its own specifics in our country.

The main goal of any election campaign of a candidate or party is to win. To do this, it is necessary to direct public interest in the direction of their candidacy in all possible ways, so that by the day of voting, the necessary number of voters would come to the polling stations and voted for him/her. Whether the methods of influencing the electoral preference Effective or not the voting record will show for the next day.

The most common method of persuading and influencing public opinion during an election campaign is campaigning. Not so long ago, the main types of campaigning were: Newspapers, television, radio, printed materials, meetings with voters, etc. Today, new media technologies have entered the arena of election communication, the role of which is increasing both in the campaigning process and in the election campaign as a whole. Despite the growing role of new media and the few examples of their intensive use in the election process in Russia, the technology of building political communication before elections using new media is currently in the process of becoming. Now most of the active voters belong to the age group over 35 years old, who are mostly not represented on the Network. Nevertheless, young people can no longer imagine their lives without the Internet, and we cannot avoid changing generations. Therefore, it is important to understand what means will be used to achieve the most effective construction of pre-election Internet communication, as well as what are the features of using new media during the pre-election period. As we can see, now there is no campaign that does not pay attention to new media. Someone invests more resources in Internet communication, someone less. All informants agreed that now new media could only be used as an auxiliary method of campaigning. The role of new media will grow more and more. The main voter of the party in power will eventually also be represented on the Network, and then we will see a real election fight in both real and virtual space.

\section{REFERENCES}

Achkasov, V. A., \& Chugunov, A. V. (1998). Democracy and the Internet: The role of the Internet in forming an enlightened understanding. In: Internet and modern society: Abstracts of the all-Russian scientific and methodical conference. St. Petersburg, pp. 43-46 p.

Alexandrov, K. A. (2011). Cartel political parties: conditions of emergence and modern transformations. In: Central Russian Bulletin of social Sciences, 2, 83-87.

Alisov, E. A., Cherdymova, E. I., Trubina, G. F., Yakushev, A. N., Zhdanov, S. P., Popova, O. V., \& Kobzar-Frolova, M. N. (2018). Study of Dominant Type of Student Ecological Focus. Ekoloji, 27(106), 357-362.

Anokhin M. G., \& Pavlyutenkova M. Yu. (2001) PR avant-garde information technology: opportunities and prospects. Public relations in politics and public administration, 408-425.

Baranov, V. V., Cherdymova, E. I., Novikov, S. B., Lukina, E. V., Kazurov, O. A., Korzhanova, A. A., \& Gurbanov, R. A. (2019). Student attitude to ethical consumption as new ecological practice. Humanities \& Social Sciences Reviews, 7(4), 1173-1179.https://doi.org/10.18510/hssr.2019.74160 
Boyarova, A. B. (2011). Updating the theme of gubernatorial elections in the context of the current political situation in Russia: a temporary relapse or a new trend? Bulletin of the Perm University. Political Science Series, 2, 102-115.

Brodovskaya, E. V. (2013). Research Methods and indicators for measuring Internet activity of political parties. Central Russian Bulletin of social Sciences, 4, 96-99.

Cherdymova, E. I., Faleeva, L. V., Ilkevich, N. G., Sharonov, I. A., Sayfutdinova, G. B., Leusenko, I. V., \& Popova, O. V. (2019). Socio-Psychological Factors that Contribute to and Impede the Process of Student EcoVocational Consciousness Formation. Ekoloji, 28(107), 133-140.

Cheredov, I. G. (2009). Evolution of definitions and typologies of political parties. Izvestiya of Russian state pedagogical University named after A. I. Herzen, 11, 309-316.

Chugunov, A. V. (2000). Politics and the Internet: political communication in the context of the development of modern information technologies: autoref. of Diss. Of PhD in polit. sciences. St. Petersburg, $27 \mathrm{p}$.

Galkin, A. A. (2000). Dynamics of political preferences in the Russian electoral corpus. Russia in the conditions of transformations. Moscow: FRPC.

Gelman, V. Ya. (1997). Creating rules of the game: Russian electoral legislation of the transition period. Political research, 4, 125-147.

Grachev, D. A. (2003). on voter confidence in the electoral Institute. Magazine about the election, 1, 53-56.

Ivanov, D. G. (2002). Use of Internet technologies by subjects of the Russian political process in the late 1990s2001: author's review of Diss of PhD in polit. sciences. Moscow, 27p.

Kaminchenko, D. I. (2013). the Impact of new media on political parties. Bulletin of the Perm University, 3, 191194.

Kislitsina, I. S. (2009). Political parties in the communicative space of the Internet. Abstract of dis. of PhD in polit. sciences. Moscow, $26 \mathrm{p}$.

Lapaeva, V. V. (2002). Political party: concept and goals. To the adoption of the law on parties. Journal of Russian law, 1, 16-25.

Losenkov, O. I. (2006). Political Internet technologies in the activities of political parties in modern Russia: Abstract. dis. of PhD in polit. sciences. Cherkessk, $26 \mathrm{p}$.

Lukina, M. M. (2010). Internet media: Theory and practice: Student book. Moscow: Aspect Press.

Martjanov, D. S. (2013). Comparative analysis of the representation of new Russian parties on the Internet. Proceedings of the Russian state pedagogical University named after A. I. Herzen, 161, 117 - 121.

Mikhaleva, G. M. (2009). Russian parties in the context of transformation. Moscow: Knizhny dom.

Ovchinnikov, B. V. (2002). Virtual hopes: the state and prospects of the political Runet. Polis, 1, 46-65.

Peskov, D. N. (2002). the Internet in Russian politics: utopia and reality. Polis, 1, 31-45.

Putilina, E. S., Cherdymova, E. I., Kurbanov, R. A., Belyalova, A. M., Shatskaya, I. I., Kobzeva, E. I., Zhuravleva, M. V., \& Meleshko, G. S. (2019). Ecological relationships in real and virtual environments: contact points. EurAsian Journal of BioSciences Eurasia J Biosci, 13, 1475-1480.

Shashkova, Ya. Yu. (2011). The Party system in the processes of political transformation and elections in the Russian Federation (on the example of the regions of South - Western Siberia): Dis. Of PhD in polit. Sciences: 23.00.02. Chita, $56 \mathrm{p}$.

Smorgunov, L. V. (2014). Network political parties. Polis. Political research, 4, 21-37. https://doi.org/10.17976/jpps/2014.04.03

Tavokin, E. P. (1996) Sociological forecasts of electoral behavior. Sociological research, 7, 15-20.

Tsabolova, O. R., Cherdymova, E. I., Ilyin, A. N., Zhukova, M. A., Tsopanova, I. G., Krasnova, L. N., Mashkin, N. A., \& Bugaeva, T. K. (2019). Ecology of psycho-emotional climate in labor collectives: Factors, problems and prospects of development. EurAsian Journal of BioSciences Eurasia J Biosci, 13, 2027-2032.

Yudaev, V. I. (2001). Internet and elections. Election technology and election art, 1, 149-159.

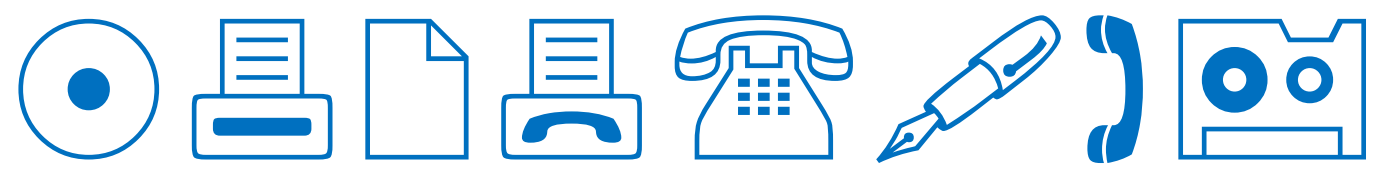

